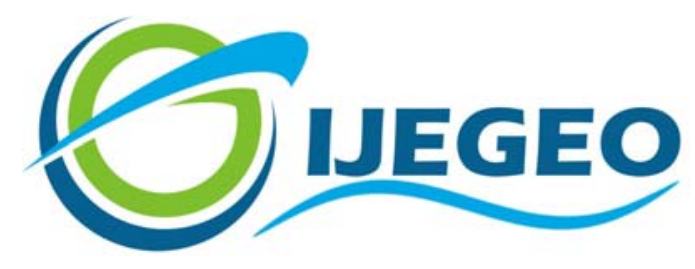

International Journal of Environment and Geoinformatics (IJEGEO) is an international, multidisciplinary, peer reviewed, open access journal.

\title{
Investigation of Changing in Agricultural Land Use after Land Consolidation Projects: A Case Study of Konya/Turkey
}

\author{
Fatih İşcan and Ceren Yağcı
}

Editors

Prof. Dr. Cem Gazioğlu, Prof. Dr. Dursun Zafer Şeker, Prof. Dr. Ayşegül Tanık, Assoc. Prof. Dr. Şinasi Kaya

\section{Guest Editors}

Assoc. Prof. Dr. Ekrem Tuşat, Asist. Prof. Dr. Fatih Sarı, Prof. Dr. Hakan Karabörk

\section{Scientific Committee}

Assoc. Prof. Dr. Hasan Abdullah (BL), Assist. Prof. Dr. Alias Abdulrahman (MAL), Assist. Prof. Dr. Abdullah Aksu, (TR); Prof. Dr. Hasan Atar (TR), Prof. Dr. Lale Balas (TR), Prof. Dr. Levent Bat (TR), Assoc. Prof. Dr. Füsun Balık Şanlı (TR), Prof. Dr. Nuray Balkıs Çağlar (TR), Prof. Dr. Bülent Bayram (TR), Prof. Dr. Şükrü T. Beşiktepe (TR), Dr. Luminita Buga (RO), Prof. Dr. Z. Selmin Burak (TR), Assoc. Prof. Dr. Gürcan Büyüksalih (TR), Dr. Jadunandan Dash (UK), Assist. Prof. Dr. Volkan Demir (TR), Assoc. Prof. Dr. Hande Demirel (TR), Assoc. Prof. Dr. Nazlı Demirel (TR), Dr. Arta Dilo (NL), Prof. Dr. A. Evren Erginal (TR), Dr. Alessandra Giorgetti (IT), Assoc. Prof. Dr. Murat Gündüz (TR), Prof. Dr. Taşkın Kavzoğlu (TR), Dr. Hakan Kaya (TR), Assoc. Prof. Dr. Kensuke Kawamura (JAPAN), Prof. Dr. Fatmagül Kılı̧̧ (TR), Prof. Dr. Ufuk Kocabaş (TR), Prof. Dr. Hakan Kutoğlu (TR), Prof. Dr. Nebiye Musaoğlu (TR), Prof. Dr. Erhan Mutlu (TR), Assist. Prof. Dr. Hakan Öniz (TR), Assoc. Prof. Dr. Hasan Özdemir (TR), Prof. Dr. Haluk Özener (TR), Assoc. Prof. Dr. Barış Salihoğlu (TR), Prof. Dr. Elif Sertel (TR), Prof. Dr. Murat Sezgin (TR), Prof. Dr. Nüket Sivri (TR), Assoc. Prof. Dr. Uğur Şanlı (TR), Assoc. Prof. Dr. Seyfettin Taş (TR), Assoc. Prof. Dr. İ. Noyan Yılmaz (TR), Assist. Prof. Dr. Baki Yokeş (TR), Assist. Prof. Dr. Sibel Zeki (TR). 


\section{Dear colleagues;}

We are very glad to meet you with "International Journal of Environment and Geoinformatics" special issue which is a compilation of proceedings presented in "SELÇUK INTERNATIONAL SCIENTIFIC CONFERENCE ON APPLIED SCIENCES" held on 27-30 September in Antalya/Turkey.

Besides Turkish scientists, The Selçuk ISCAS 2016 brought together Russian, Ukrainian, Kazakhstan, Azerbaijani, Persian, Algerian, Nigerian, Netherlander, Scottish, Liberian, Philippines and Czech Republican scientists. Turkey General Directorate of Land Registry and Cadastre, Republic of Turkey Ministry of Food, Agriculture and Livestock Undersecretary, International Federal of Surveyors (FIG) and International Society for Photogrammetry and Remote Sensing (ISPRS) contribute to The Selçuk ISCAS 2016 at board of director's level.

The Selçuk International Scientific Conference on Applied Sciences (The Selçuk ISCAS 2016) held in Antalya on 27-30, September 2016. The Selçuk ISCAS 2016 is a candidate of one of the most important event in the scientific schedule and tenders a possibility for researchers and academicians who researches on applied sciences. You can find a first class programme of plenary speakers, technical sessions, exhibitions and social events in this book. You will be able to catch up with the developments in Geographical Information Sciences, Information Technology, Environmental Management and Resources, Sustainable Agriculture, Surveying, Photogrammetry and Remote Sensing, meet friends and experience the traditional and fascinating culture of TURKIYE. As an international conference in the field of geo-spatial information and remote sensing, The Selçuk ISCAS 2016 is devoted to promote the advancement of knowledge, research, development, education and training in Geographical Information Sciences, Information Technology, Environmental Management and Resources, Sustainable Agriculture, Surveying, Photogrammetry and Remote Sensing, their integration and applications, as to contribute to the well-being of humanity and the sustainability of the environment. The Conference of Selçuk ISCAS 2016 will provide us an opportunity to examine the challenges facing us, discuss how to support Future Earth with global geo-information, and formulate the future research agenda.

195 scientists from 13 countries attended to the symposium. 105 oral presentations, 40 fast oral presentations and 50 poster presentations are presented during the symposium. 145 oral and fast oral presentations take place in 24 technical sessions in two days. On the other hand, 5 invited speaker presentations held in the plenary session in the first day.

The conference is carried out with the support of the organizations as the Selçuk University, General Directorate of Land Registry and Cadastre, General Directorate Of Agricultural Reform, Turkish Cooperation and Development Agency (TIKA), International Federation of Surveyors (FIG) and International Society for Photogrammetry and Remote Sensing (ISPRS). In addition, the symposium is also supported by the commercial organizations of Paksoyteknik, Mescioğlu, Geogis, Körfez, Tümaş, 4B Ölçüm, GNSS Teknik, Arbiotek ve Anıt Hospital.

Best wishes.

Assoc. Prof. Dr. Ekrem Tuşat

Asist. Prof. Dr. Fatih Sarı

Prof. Dr. Hakan Karabörk 


\title{
Investigation of Changing in Agricultural Land Use after Land Consolidation Projects: A Case Study of Konya/Turkey
}

\author{
Fatih İşcan* and Ceren Yağcı \\ Selçuk University, Engineering Faculty, Department of Geomatic Engineering, 42075Konya, TR \\ Corresponding author. \\ Received: 01 November 2016 \\ E-mail: fiscan@selcuk.edu.tr \\ Accepted: 26 December 2016
}

\begin{abstract}
Land consolidation projects have serves for rural development. Land consolidation projects have an important role in ensuring agricultural development. Therefore, the number of land consolidation applications is increased in Turkey in recent years. It is necessary to prevent land fragmentation for ensuring the sustainability of these projects.

The aim of this study is to examine the changing in agricultural parcels of landowner after the land consolidation projects. In this paper, study area is chosen Ağalar/KONYA village where land consolidation implemented in 2003. 2010 and 2015 google earth images of study area are digitized in Netcad software. The digitized cadastral sheets of Ağalar/KONYA village which is done land consolidation project is overlayed with digitized data of 2010 and 2015 google earth images to evaluate changes in agricultural parcels. In additionally, questionnaire was done with landowners for their opinions about land consolidation project. According to the results, $60 \%$ of the landowner is satisfied with land consolidation project. While the number of parcels was 762 in 2003, the number of parcels was found 729 in 2010 and 723 in 2015.
\end{abstract}

Keywords: Land consolidation, agricultural parcel, landowner, digitized data.

\section{Introduction}

Land consolidation is an excellent tool for promoting the primary production of food staples, improving working conditions in agriculture and the living conditions of people living in rural areas in the course of coordinating urban and rural development (Huang, 2011).It is also an instrument for sustainable rural development in a wider context which includes improvements in agricultural production, employment, infrastructure, public facilities, housing and the protection of natural resources (Pašakarnis, 2010).

In view of these considerations, numerous land consolidation (LC) and land reform policies have been implemented to reduce fragmentation in European countries like the Netherlands, France, Spain, Czech Republic or Turkey; in African countries like Kenya, Tanzania and Rwanda; in China, Japan, India and elsewhere (Rosman and Sonnenberg, 1998; Akkaya Aslan and Arici, 2005; Wu et al., 2005;
Miranda et al., 2006; Sklenicka, 2006; Tan et al., 2006, Akkaya Aslan, 2007).

In Turkey, LC study is not implemented only as a reallocation of lands, but together with such works as irrigation, drainage, road system, land levelling, and land improvement. Nowadays, LC work is being carried out only in places where irrigated agriculture is practiced. No practice has yet been carried out in the areas without irrigated agriculture. All the project expenses are paid by the state, and participators do not pay for anything. However, some of the areas that are needed for the infrastructure facilities to be built on (such as irrigation, drainage, and road) are taken from the land of the participants (in equal ratio proportional to the size of the lands) without the state paying indemnity for expropriation (Akkaya Aslan, 2007).

The aim of this study is to examine the changing in agricultural parcels after the land consolidation projects. Ilgin-Agalar part of Konya Province (Turkey) was selected as a study site where land consolidation implemented in 2003. Changes in agricultural 
parcels are evaluated by Google earth images in 2010 and 2015.

\section{Material and Methods}

Ağalar Village has a population of 740 people and 200 houses. Villagers grow sugar beet at the amounts to be determined by the grain, vegetable and sugar factory in the area. Nearly no fruit or vegetable cultivations performed in the land consolidation field. Irrigation water is provided from underground resources and, at certain times of the year, through a channel from Lake Cavuscu (Fig. 1) ( Cay and İşcan 2011).

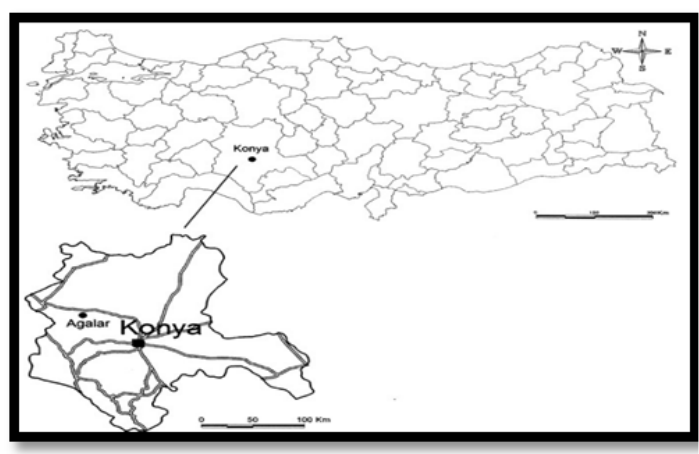

Figure 1.Study Area

The area of the Agalar Village land consolidation project is 1403 ha, 1388 ha of which is arranged as follows: 9894 ha as agricultural land, 2887 ha as pasture and 109.9 ha as expropriation area created previously by the Directorate General of State Hydraulic Works. There are 715 farmers (and 1536 cadastral parcels in the consolidation field). Three hundred and eighty three of these cadastral parcels are shared parcels. The average size of cadastral parcels is 0.6441 ha (İşcan, 2011). After Land consolidation, it has been formed 762 parcels in 76 blocks (Fig.2). The average parcel size is consists about $18 \mathrm{da}$.

Google Earth images are used for analyze the parcel changes in 2010 and 2015 (Fig. 3). Global mapper software is used for coordinate transformation of Google earth images. Also, Netcad software is used for the digitization of images. Questionnaire was made taking into account the data of the year 2003, 2010 and 2015 in study area.

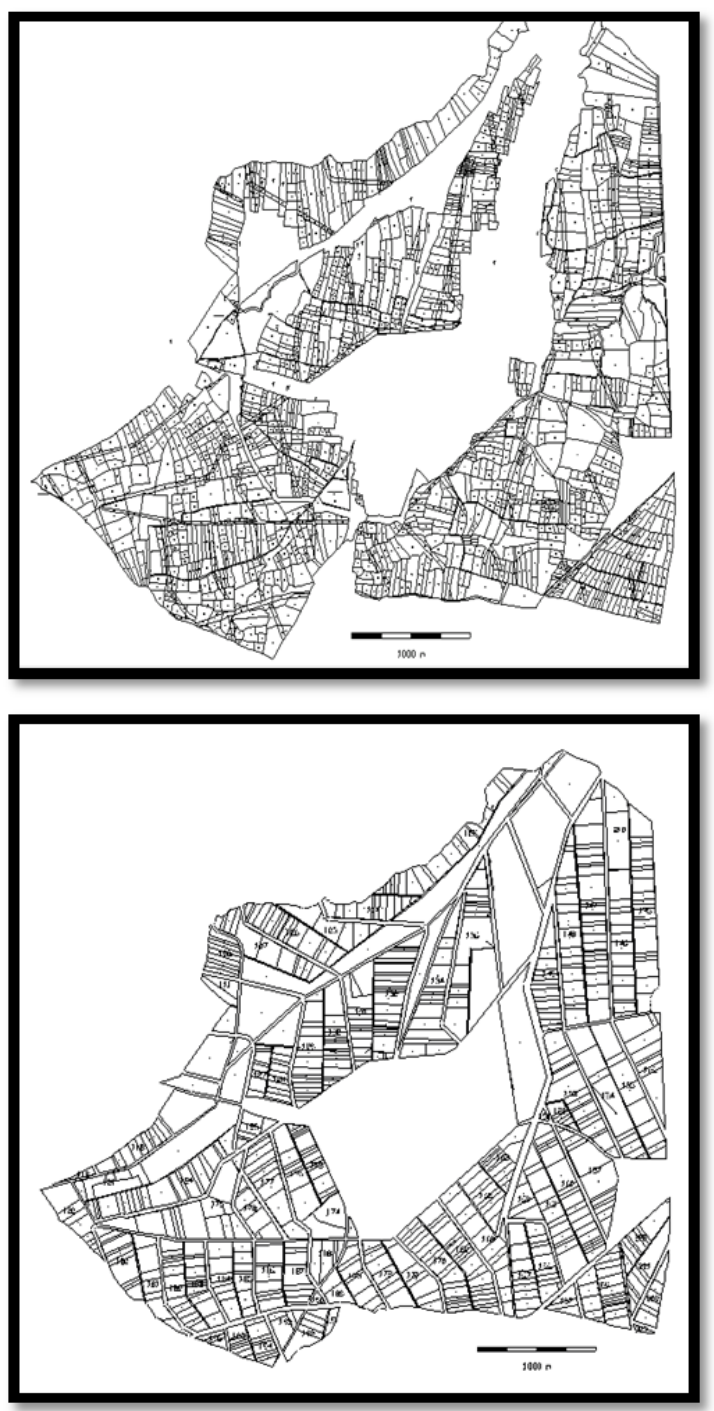

Figure 2: Cadastral sheets (Before (a) and after (b) Land Consolidation)

\section{Results and Discussion}

Digital image in 2003 has ED50 datum and WGS-84 projection. Global Mapper software was used to convert into the same coordinate system to raster images of 2010 and 2015. 

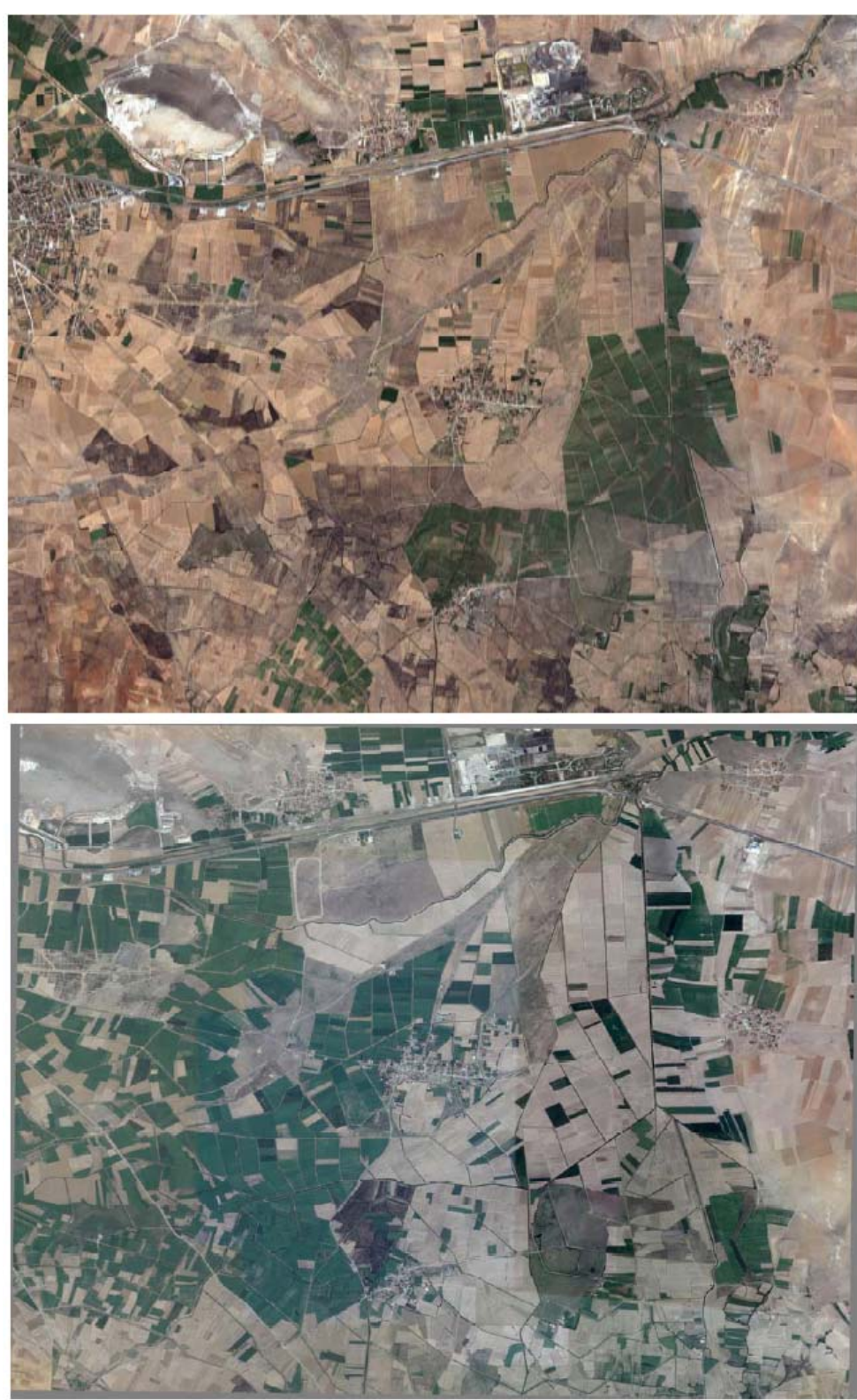

Figure 3: Google Earth images is from 2015 (a) /2010 (b)

After transformation process, images were overlay with NETCAD software and digitizing were performed (Fig. 4). After digitizing, the numbers of blocks/parcels were examined according to the years. Changes of parcel numbers in the blocks have been examined after land consolidation. It was determined that a reduction in the number of parcels of 30 (30
$\%)$ blocks and an increased in the number of parcels of 27 (26\%) blocks and constant in the number of parcels of $19(25 \%)$ blocks in 2010. It was determined that a reduction in the number of parcels of 37 (49\%) blocks and an increased in the number of parcels of $23(30 \%)$ blocks and constant in the number of parcels of $16(21 \%)$ blocks in 2015. 

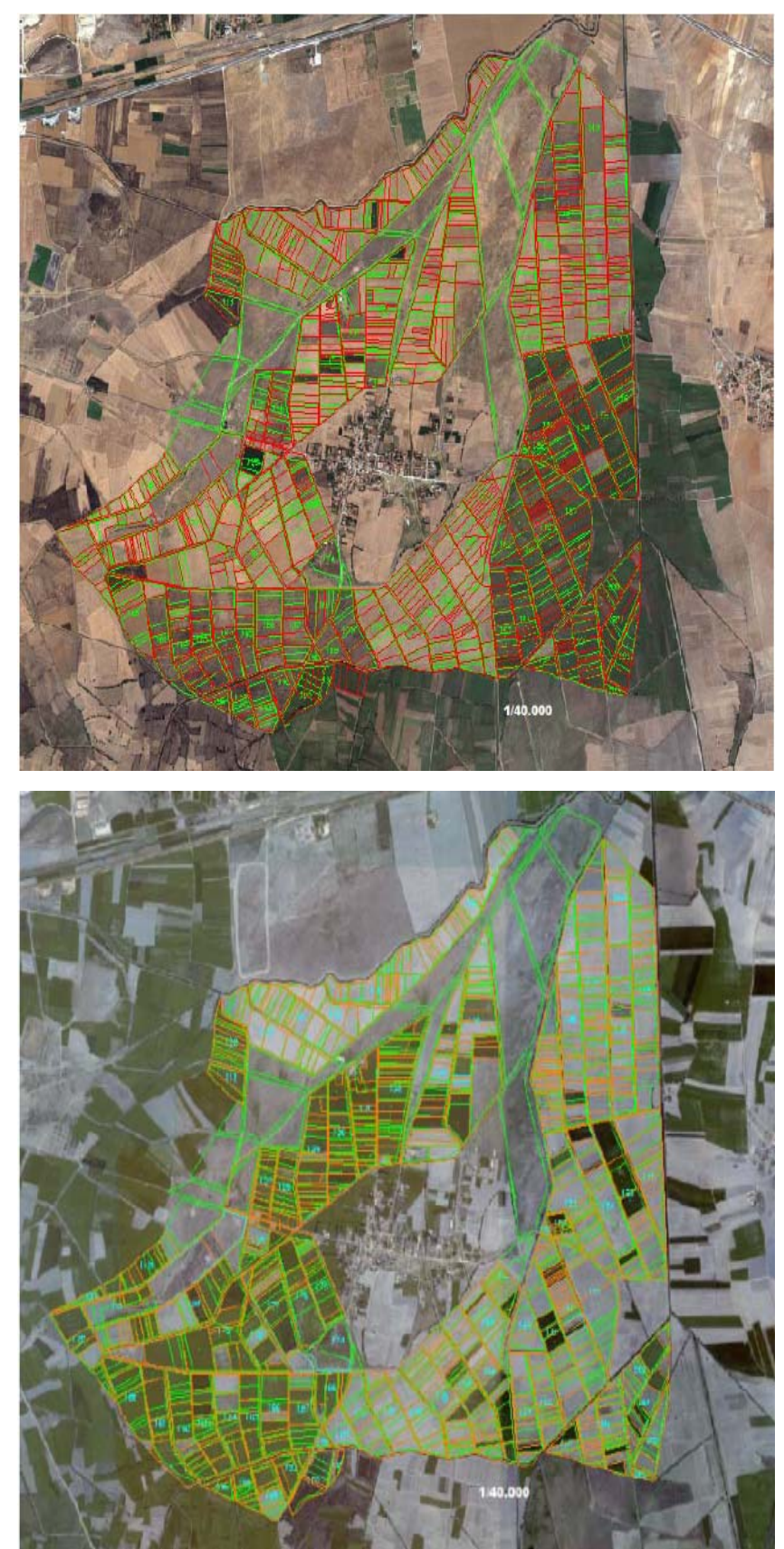

Figure 4. The digitized image of the 2003-2010 (a) / 2003-2015 (b)

When parcel changes examined between 2010 and 2015 , it was determined that a reduction in the number of parcels of 26 (34\%) blocks and an increased in the number of parcels of 23 (30 $\%$ ) blocks and constant in the number of parcels of 27 (36\%) blocks. Changes in the number of parcels are shown according to years in Table 1. The number of parcels is 762 in 2003, 729 in 2010 and 723 in 2015. 
Table 1. Changes in the number of parcels according to years

\section{Number of parcels in blocks according to years}

\begin{tabular}{|c|c|c|c|c|c|c|c|}
\hline $\begin{array}{c}\text { Block } \\
\text { No }\end{array}$ & 2003 & 2010 & 2015 & $\begin{array}{c}\text { Block } \\
\text { No }\end{array}$ & 2003 & 2010 & 2015 \\
\hline 101 & 23 & 24 & 27 & 166 & & 9 & 8 \\
\hline
\end{tabular}

\begin{tabular}{|l|l|l|l|l|l|l|l|}
\hline No & & & & No & & & \\
\hline $\mathbf{1 0 1}$ & 23 & 24 & 27 & $\mathbf{1 6 6}$ & 10 & 9 & 8 \\
\hline $\mathbf{1 0 4}$ & 11 & 10 & 12 & $\mathbf{1 6 7}$ & 9 & 11 & 10 \\
\hline $\mathbf{1 0 5}$ & 5 & 8 & 6 & $\mathbf{1 6 8}$ & 12 & 13 & 15 \\
\hline $\mathbf{1 0 6}$ & 17 & 15 & 14 & $\mathbf{1 6 9}$ & 20 & 18 & 20 \\
\hline
\end{tabular}

\begin{tabular}{|l|l|l|l|l|l|l|l|}
\hline $\mathbf{1 0 7}$ & 11 & 12 & 10 & $\mathbf{1 7 0}$ & 17 & 16 & 17 \\
\hline $\mathbf{1 0 8}$ & 9 & 7 & 8 & $\mathbf{1 7 1}$ & 7 & 7 & 7 \\
\hline $\mathbf{1 1 1}$ & 2 & 2 & 2 & $\mathbf{1 7 2}$ & 8 & 7 & 8 \\
\hline $\mathbf{1 1 8}$ & 11 & 12 & 12 & $\mathbf{1 7 3}$ & 9 & 8 & 4 \\
\hline
\end{tabular}

\begin{tabular}{|l|l|l|l|l|l|l|l|}
\hline $\mathbf{1 1 8}$ & 11 & 12 & 12 & $\mathbf{1 7 3}$ & 9 & 8 & 4 \\
\hline $\mathbf{1 1 9}$ & 3 & 2 & 2 & $\mathbf{1 7 4}$ & 1 & 1 & 1 \\
\hline $\mathbf{1 2 0}$ & 8 & 7 & 5 & $\mathbf{1 7 5}$ & 14 & 8 & 8 \\
\hline $\mathbf{1 2 1}$ & 7 & 5 & 6 & $\mathbf{1 7 6}$ & 7 & 5 & 5 \\
\hline $\mathbf{1 2 4}$ & 22 & 23 & 17 & $\mathbf{1 7 7}$ & 9 & 8 & 8 \\
\hline
\end{tabular}

\begin{tabular}{|c|c|c|c|c|c|c|c|}
\hline & & & & & & & \\
\hline 124 & 22 & 23 & 17 & 177 & 9 & 8 & 8 \\
\hline 125 & 6 & 3 & 4 & 178 & 7 & 5 & 5 \\
\hline 127 & 8 & 4 & 3 & 179 & 12 & 14 & 10 \\
\hline 128 & 10 & 6 & 6 & 180 & 11 & 6 & 5 \\
\hline
\end{tabular}

\begin{tabular}{|c|c|c|c|c|c|c|c|}
\hline & & & & & & & \\
\hline 129 & 16 & 17 & 17 & 181 & 7 & 7 & 6 \\
\hline 130 & 16 & 18 & 14 & 182 & 14 & 11 & 10 \\
\hline
\end{tabular}

\begin{tabular}{|l|l|l|l|l|l|l|l|}
$\mathbf{1 3 0}$ & 16 & 18 & 14 & $\mathbf{1 8 2}$ & 14 & 11 & 10 \\
\hline $\mathbf{1 3 1}$ & 14 & 12 & 12 & $\mathbf{1 8 3}$ & 12 & 10 & 10 \\
\hline $\mathbf{1 3 2}$ & 25 & 26 & 29 & $\mathbf{1 8 4}$ & 8 & 8 & 8
\end{tabular}

\begin{tabular}{|l|l|l|l|l|l|l|l|}
\hline $\mathbf{1 3 2}$ & 25 & 26 & 29 & $\mathbf{1 8 4}$ & 8 & 8 & 8 \\
\hline $\mathbf{1 3 4}$ & 14 & 14 & 11 & $\mathbf{1 8 5}$ & 7 & 5 & 4 \\
\hline $\mathbf{1 3 6}$ & 17 & 22 & 19 & $\mathbf{1 8 6}$ & 8 & 5 & 5 \\
\hline
\end{tabular}

\begin{tabular}{|l|l|l|l|l|l|l|l}
$\mathbf{1 3 6}$ & 17 & 22 & 19 & $\mathbf{1 8 6}$ & 8 & 5 & 5 \\
\hline $\mathbf{1 4 5}$ & 19 & 15 & 18 & $\mathbf{1 8 7}$ & 8 & 3 & 4 \\
\hline $\mathbf{1 4 6}$ & 14 & 14 & 14 & $\mathbf{1 8 8}$ & 4 & 4 & 5
\end{tabular}

\begin{tabular}{|l|l|l|l|l|l|l|l}
$\mathbf{1 4 6}$ & 14 & 14 & 14 & $\mathbf{1 8 8}$ & 4 & 4 & 5 \\
\hline $\mathbf{1 4 7}$ & 25 & 26 & 26 & $\mathbf{1 8 9}$ & 2 & 2 & 1 \\
\hline $\mathbf{1 4 8}$ & 17 & 18 & 17 & $\mathbf{1 9 0}$ & 1 & 1 & 1
\end{tabular}

\begin{tabular}{|l|l|l|l|l|l|l|l|}
$\mathbf{1 4 8}$ & 17 & 18 & 17 & $\mathbf{1 9 0}$ & 1 & 1 & 1 \\
\hline $\mathbf{1 4 9}$ & 14 & 13 & 20 & $\mathbf{1 9 1}$ & 1 & 1 & 2 \\
\hline $\mathbf{1 5 1}$ & 1 & 1 & 1 & $\mathbf{1 9 2}$ & 5 & 5 & 2 \\
\hline $\mathbf{1 5 2}$ & 6 & 4 & 5 & $\mathbf{1 9 3}$ & 4 & 4 & 4 \\
\hline
\end{tabular}

\begin{tabular}{|l|l|l|l|l|l|l|l|}
$\mathbf{1 5 1}$ & 1 & 1 & 1 & $\mathbf{1 9 2}$ & 5 & 5 & 2 \\
\hline $\mathbf{1 5 2}$ & 6 & 4 & 5 & $\mathbf{1 9 3}$ & 4 & 4 & 4 \\
\hline $\mathbf{1 5 3}$ & 18 & 22 & 21 & $\mathbf{1 9 4}$ & 8 & 3 & 6 \\
\hline
\end{tabular}

\begin{tabular}{|l|l|l|l|l|l|l|l|}
\hline $\mathbf{1 5 3}$ & 18 & 22 & 21 & $\mathbf{1 9 4}$ & 8 & 3 & 6 \\
\hline $\mathbf{1 5 4}$ & 10 & 14 & 14 & $\mathbf{1 9 5}$ & 8 & 3 & 6 \\
\hline $\mathbf{1 5 5}$ & 10 & 12 & 11 & $\mathbf{1 9 6}$ & 3 & 2 & 2 \\
\hline $\mathbf{1 5 6}$ & 9 & 10 & 11 & $\mathbf{1 9 7}$ & 3 & 3 & 2 \\
\hline
\end{tabular}

\begin{tabular}{|c|c|c|c|c|c|c|c|}
\hline & & & & & & & \\
\hline 155 & 10 & 12 & 11 & 196 & 3 & 2 & 2 \\
\hline 156 & 9 & 10 & 11 & 197 & 3 & 3 & 2 \\
\hline 157 & 12 & 12 & 12 & 199 & 18 & 20 & 21 \\
\hline 160 & 18 & 20 & 27 & 200 & 9 & 11 & 8 \\
\hline 161 & 12 & 13 & 13 & 201 & 7 & 6 & 8 \\
\hline 162 & 4 & 5 & 5 & 202 & 6 & 6 & 4 \\
\hline 163 & 11 & 11 & 11 & 203 & 1 & 1 & 1 \\
\hline 165 & 8 & 10 & 8 & 210 & 2 & 3 & 2 \\
\hline
\end{tabular}

\section{Unchanged parcels borders}

It was observed that all parcel borders of 193 th block and the number of 1, 2, 3, 4 parcels on 120 th block is constant respectively in 2010 and 2015(Fig. 5)

\section{Parcel Fragmentation}

It was observed that the number of 6 parcel on 160 th block is divided into 8 parcels in 2010. It was observed that the number of 5 parcel on 155 th block is divided into 4 parcels in 2015 (Fig.7). 


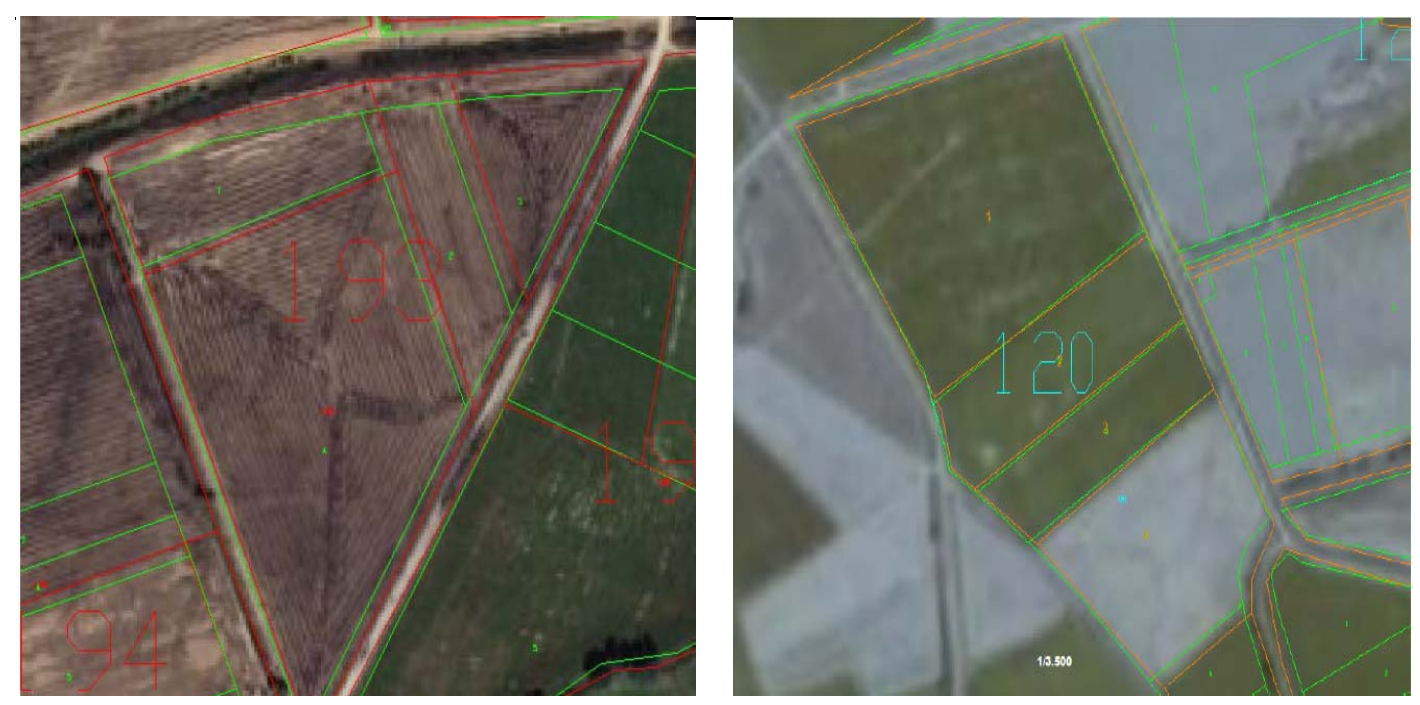

Figure 5. Unchanged parcels in 2010 (a)/2015 (b)
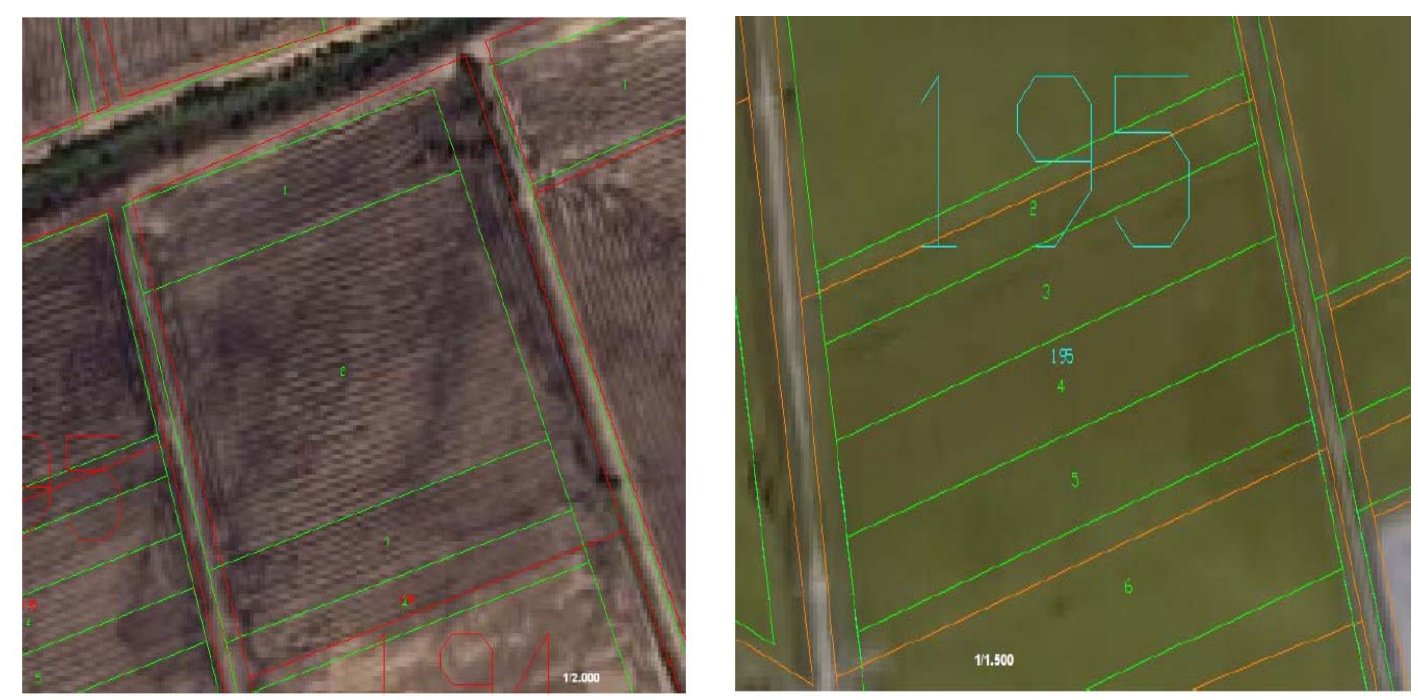

Figure 6. Merged Parcels in 2010 (a)/2015 (b)

\section{Changed parcels borders}

It was observed that parcel borders of 192 th and 152 th block is changed respectively in 2010 and 2015 (Fig. 8).

In additionally, Questionnaire was done with landowners for their opinions about land consolidation project. A total of 57 questionnaires were made. 

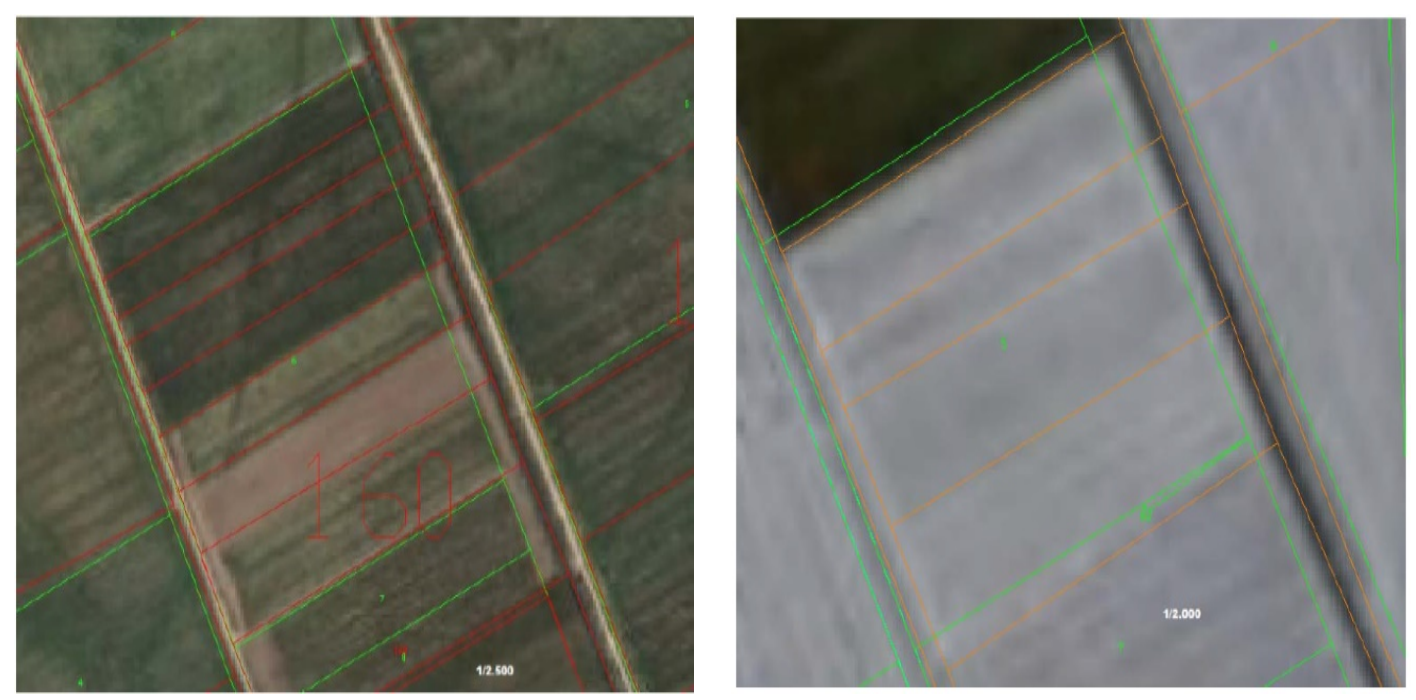

Figure 7. Examples of scattered parcels in 2010 (a) /2015 (b)
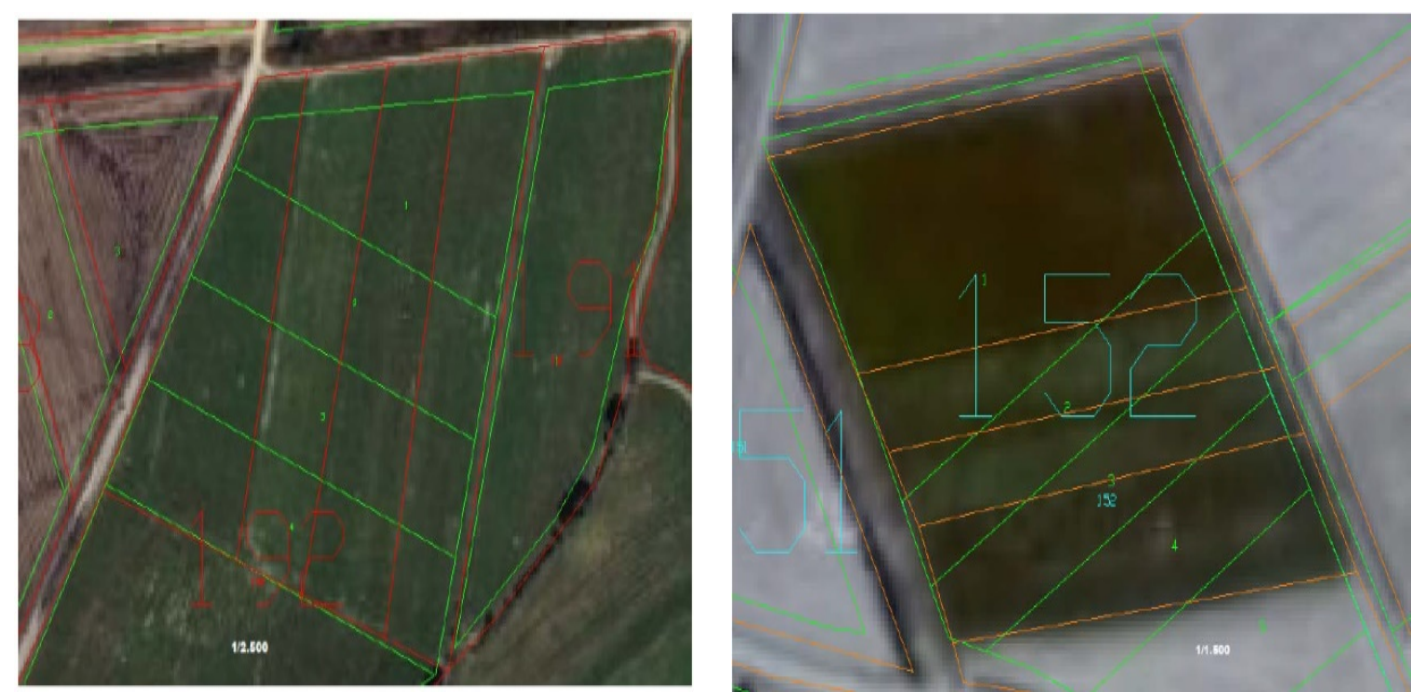

Figure 8. Changed parcels borders in 2010 (a) / 2015(b) 
Landowners were asked whether they are pleased or not in informing about land consolidation before land consolidation application. Their answers were $2 \%$ well pleased, $40 \%$ pleased, $28 \%$ 'neutral, $23 \%$ not pleased, $7 \%$ not so pleased (Graphic 1).

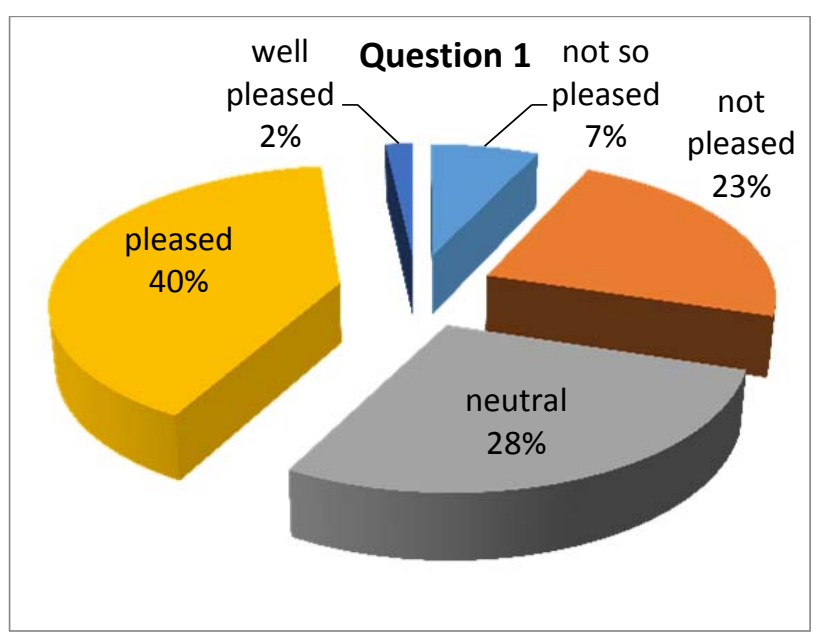

Graphic 1: Pleasure graphic of the informing the landowners which are related to land consolidation prior to project implementation.

Landowners were asked whether they are pleased or not reduction of the number of parcels after land consolidation application.
Their answers were $20 \%$ well pleased, $64 \%$ pleased, $7 \%$ neutral, $5 \%$ not pleased, $4 \%$ not so pleased (Graphic 2).

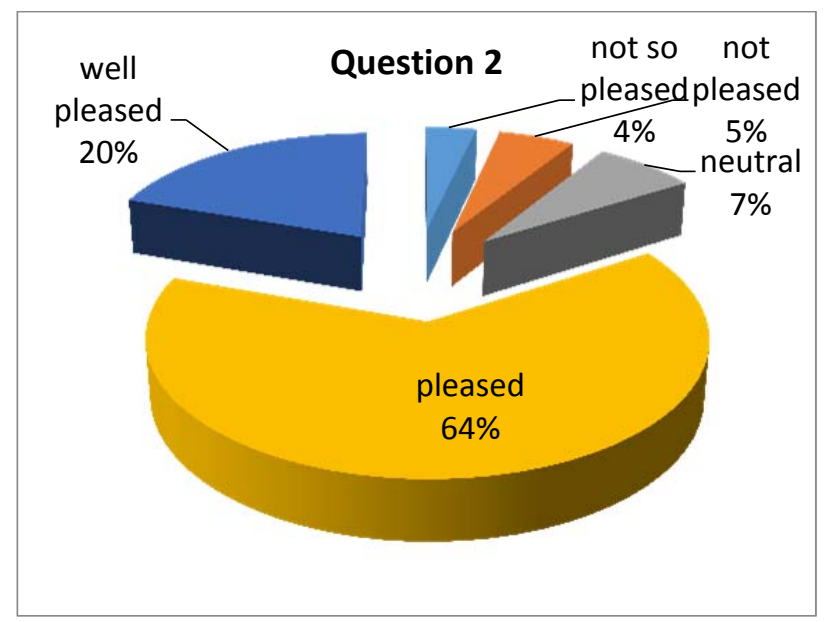

Graphic 2: Pleasure graphic of the landowners about reduction of the number of parcels after project.

Landowners were asked whether they are pleased or not agricultural productivity after land consolidation project. Their answers were
$26 \%$ well pleased, $47 \%$ pleased, $12 \%$ neutral, $11 \%$ not pleased, $4 \%$ not so pleased (Graphic 3). 


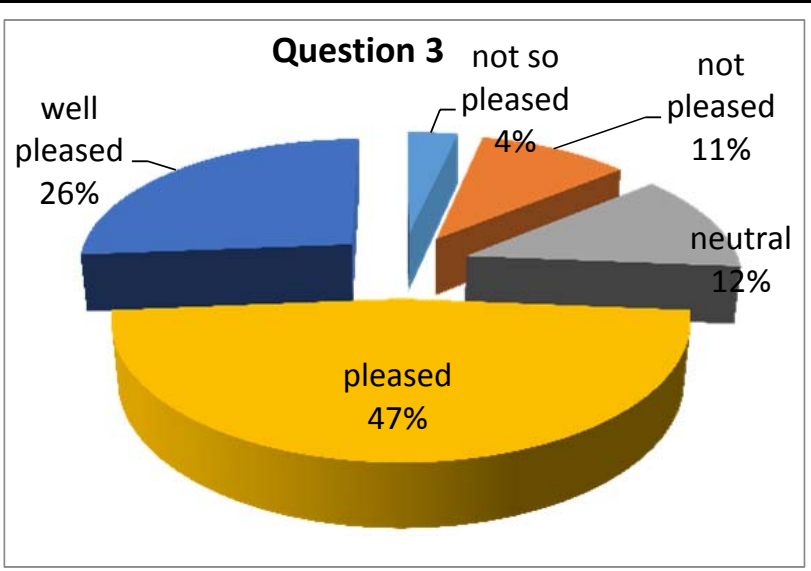

Graphic 3: Pleasure graphic of the landowners about productivity changes that occur in parcels after project.

Landowners were asked whether they are pleased or not to comply with interviews in land reallocation phase of land consolidation.
Their answers were $18 \%$ well pleased, $46 \%$ pleased, $10 \%$ neutral, $17 \%$ not pleased, $9 \%$ not so pleased (Graphic 4).

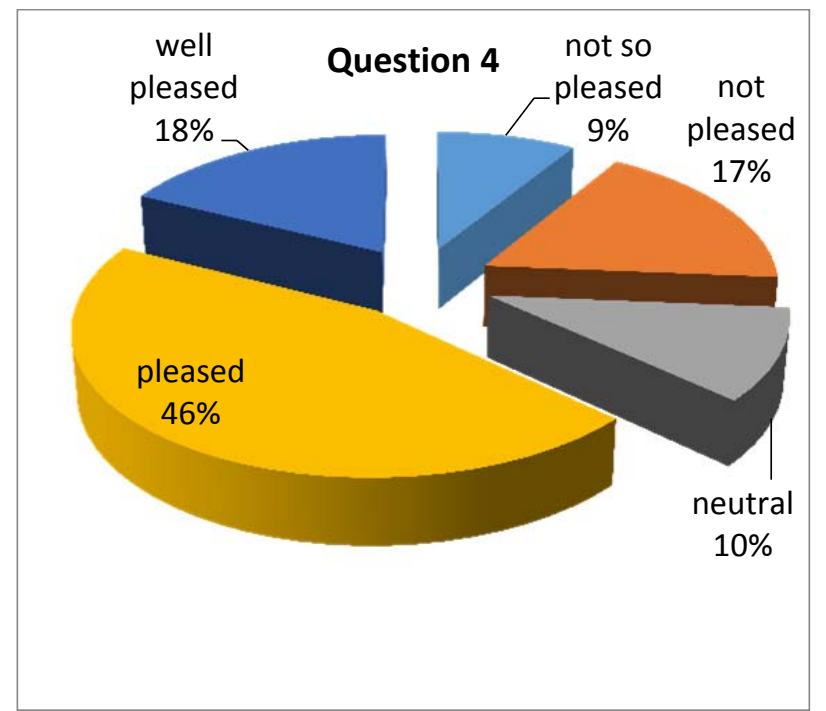

Graphic 4: Pleasure graphic of the landowners about interviews related to compliance with the distribution

Landowners were asked whether they are pleased or not about land consolidation project which carried out in Ağalar village. Their answers were $24 \%$ well pleased, $60 \%$ pleased, $2 \%$ neutral, $7 \%$ not pleased, $7 \%$ not so pleased (Graphic 5). 


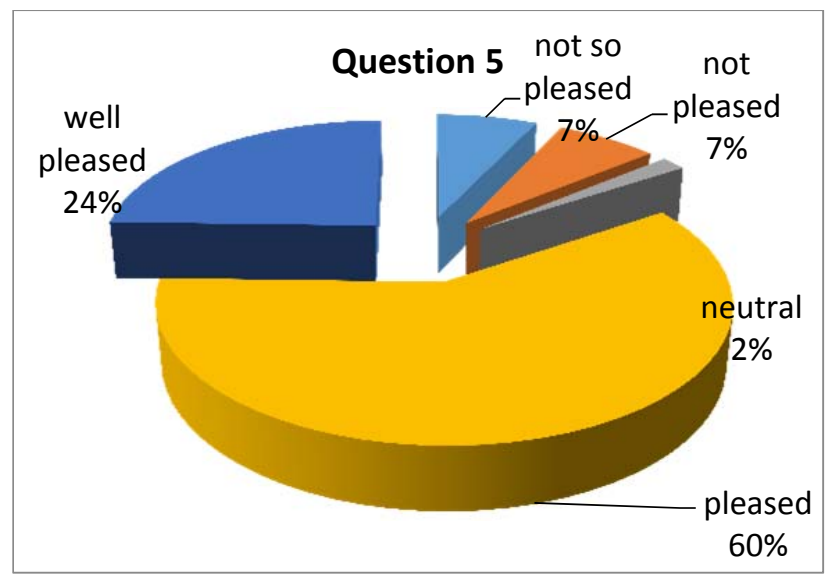

Graphic 5: Pleasure graphic of the landowners about the land consolidation project which carried out in Ağalar village.

\section{Conclusions}

As a result of the research, parcel numbers in $75 \%$ of the blocks between 2003-2010, $79 \%$ of the blocks between 2003 and 2015 and $65 \%$ of the blocks between 2010 and 2015 changed after land consolidation project was carried out Ağalar/KONYA village in 2003. The reason of the decreasing in the number of parcels is the merger of the neighboring parcels. Because, landowners of neighboring parcels are relative to each other. Landowners are used this parcels together. Conversely, parcels in 2010 and 2015 have fragmented due to inheritance and sales.

According to questionnaire, $84 \%$ of landowners are pleased about land consolidation project, $42 \%$ of them are pleased informing the landowners which are related to land consolidation, $84 \%$ of them are pleased about reduction of the number of parcels after land consolidation project, $73 \%$ of them are pleased about agricultural productivity after land consolidation project, $64 \%$ of them are pleased about comply with interviews in land reallocation phase of land consolidation. In addition, they are complaining lack of irrigation channels after land consolidation project.

In order to ensure sustainability after the land consolidation projects, existing situation should be protected and land fragmentation should be prevented. Heritage is the most important cause of land fragmentation in Turkey. Inheritance law and related laws should be changed for preventing land fragmentation.

\section{References}

Akkaya Aslan S.T. and Arıcı I. (2005): GISsupported land consolidation planning information system: ARTOP. Bodenkultur 56(2): 103-110.

Akkaya Aslan T., Gundogdu K. S., Yasloglu E., Kirmıkıl M. and Arıc1 I. (2007): Personal, physical and socioeconomic factors affecting farmers' adoption of land consolidation Spanish Journal of Agricultural Research, 5(2): 204-213.

Çay,T. and İşcan F. (2011): Fuzzy Expert System For Land Reallocation In Land Consolidation, Expert Systems With Applications, 38(9): 11055-11071.

Huang Q, Li M., Chen, Z. and Li F. (2011): Land Consolidation: An Approach for Sustainable Development in Rural China, AMBIO ,40(1): 93-95.

İşcan, F. (2009): Application of fuzzy logic in land consolidation activities. Ph.D. Thesis, Selcuk University, Institute of the Natural and Applied Sciences. Konya, Turkey (in Turkish).

Miranda D., Crecente R. and Álvarez M.F. (2006): Land consolidation in inland rural Galicia, NW Spain, since 1950: an example of the formulation and use of questions, criteria and indicators for evaluation of rural development policies. Land Use Policy, 23(4): 511-520. 
Pašakarnis G. and Maliene V. (2010): Towards sustainable rural development in Central and Eastern Europe: Applying land consolidation, Land Use Policy, 27(2): 545549.

Rosman F.B. and Sonnenberg J. (1998): New method for the design of reallocation plan in land consolidation projects, XXI FIG International Congress, Brighton: 19-25.

Sklenicka P. (2006): Applying evaluation criteria for the land consolidation effect to three contrasting study areas in the Czech Republic. Land Use Policy, 23(4): 502-510.

Tan S., Heerink N. and Qu F. (2006): Land fragmentation and its driving forces in China. Land Use Policy, 23(3): 272-285.

Wu Z., Luu M. and Davis J. (2005): Land consolidation and productivity in Chinese household crop production. China Econ Rev 16:29-49. 